\title{
Quality based payment program and milk quality in dairy cooperatives of Southern
}

\section{Brazil: an econometric analysis}

\author{
Bruno Garcia Botaro ${ }^{1}$, Augusto Hauber Gameiro², Marcos Veiga dos Santos²*
}

1USP/FMVZ - Depto. de Medicina Veterinária Preventiva e Saúde Animal.

2USP/FMVZ - Depto. de Nutrição e Produção Animal, Av. Duque de Caxias Norte, 225 - 13635-900 -

Pirassununga, SP - Brasil.

*Corresponding author <mveiga@usp.br>

Edited by: Daniel Scherer de Moura

Received December 13, 2011

Accepted August 08, 2012
ABSTRACT: Programs designed to enhance milk quality have been used to motivate dairy farmers to improve the quality of the raw milk they produce. The objective of this study was to evaluate the association between a milk quality payment program and four indicative variables of milk quality, by testing bulk tank somatic cell count (SCC), bulk tank total bacterial count (TBC), fat (FAT) and protein (PROT) percentages over three years in four dairy cooperatives in Southern Brazil. We used a multiple regression econometric model estimated from market data of milk delivered by farmers to the cooperatives. Bulk tank milk samples $(n=19,644)$ were monthly collected. The data set was analyzed for the effects of seasonality, average daily volume of milk, the award/penalty, producer, and cooperatives on SCC, TBC, FAT and PROT. Results suggested an association between the adoption of a payment program based on milk quality and the reduction of SCC and TBC. Nevertheless, the program seems to have not contributed to increase fat and protein milk percentages. This information may help the dairy industry in developing countries to conceive strategies to enhance overall milk quality.

Keywords: bacterial count, somatic cell count, premium payment, milk composition, milk production

\section{Introduction}

Milk quality is an important aspect of dairy production that affects milk processing, its technological properties, and thus economical efficiency (Auldist and Hubble, 1998; Barbano et al., 2006). Dairy industries worldwide have instituted penalty and premium programs to provide incentives for dairy producers to improve milk quality (Schukken et al., 1992a,b; Nightingale et al., 2008). Most of these programs are focused on bulk tank milk quality, such as total bacterial count (TBC), somatic cell count (SCC) and milk composition (percentage of fat, protein and solids non-fat) (Draaiyer et al., 2009; Dekkers et al., 1996). Premium payments motivate farmers to produce high quality milk without disrupting the milk supply chain of the market they operate (Nightingale et al., 2008). However, the degree that this inducement affects overall milk quality in developing countries is not documented in the literature. Brazilian milk ordinance currently allows an upper limit of 750,000 cells $\mathrm{mL}^{-1}$ both for bulk tank somatic cell and total bacterial counts (Brasil, 2002), which might compromise trading of the country's dairy products, as legal limits for SCC and TBC at international level are generally lower. In Europe, for instance, the EEC directive 92/46 established legal limits of 400,000 cells $\mathrm{mL}^{-1}$ and $100,000 \mathrm{cfu} \mathrm{mL}^{-1}$, for SCC and $\mathrm{TBC}$, respectively, while the USA and Canada have limited SCC to 750,000 and 500,000 cells $\mathrm{mL}^{-1}$, respectively (Sargeant et al., 1998). Quality premiums paid to producers have proven their effectiveness in influencing milk quality (Schukken et al., 1992a; Valeeva et al., 2007; Nightingale et al., 2008).

We hypothesized that monetary incentives offered to dairy producers can encourage them to improve overall milk quality parameters, not only those related to udder health and milk hygiene procedures (i. e., somatic cell and total bacterial counts, respectively), but also milk composition (percentages of milk fat and protein). Thus, the aim of this study was to evaluate the influence of a milk quality payment program adopted by a dairy central cooperative in Brazil on milk quality of dairy products by monthly testing of bulk tank somatic cells (BTSCC), bulk tank total bacterial count (BTTBC), fat (FAT) and protein (PROT) percentages during three years.

\section{Materials and Methods}

Data used for this study were collected from a dairy central cooperative in Southern Brazil, from Aug. 2005 through Apr. 2008, accumulating 19,644 observations. Each observation corresponds to the total volume delivered by a producer in one month, with monthly weighted average indicators of BTSCC, BTTBC, FAT and PROT. This central cooperative was a tier of four small cooperatives (A, B, C and D) which had, respectively, 203, 92, 321 and 459 permanent dairy producers whose total milk production was delivered to the central cooperative (Table 1). Milk delivered during the period of data collection was mainly destined for powder milk production.

Bulk tank samples were monthly collected and milk composition analyses were performed using Bentley 2000 (Bentley Instruments, Chaska, MN) to determine fat and protein percentages, Somacount 300 (Bentley Instruments, Chaska, MN) and BactoScan (Foss Electric, Hillerød, Denmark) for somatic cell and total bacteria counts, respectively.

The recorded data set included producer identification (anonymous and individually identified by a numerical code), and the monthly producer's BTSCC and BTTBC, FAT and PROT percentages, and whether dairy 
producer had/had not achieved milk quality goals adopted by the cooperative for each parameter. Observations were omitted for missing values in any analyzed category. Each producer's daily average volume of milk (L day ${ }^{-1}$ ) was obtained by dividing the total volume delivered by a producer on a monthly basis. Premium was the grant paid to the producer if quality targets were achieved.

The development of the premium program adopted by the cooperative was based on targets currently established by federal regulation (Brasil, 2002) for dairy farmers' bulk tank somatic cell and total bacterial counts in the period of the study, and also balanced to fulfill market demands for milk quality. Before implementation of the premium program, the central cooperative focused on capacity-building and knowledge delivery to each of its cooperatives' dairy extension personnel. It was intended that each one of the four cooperatives, by means of their extension personnel, would be responsible for training farmers in management practices to achieve milk quality goals (Nettle et al., 2003). The adopted extension approach was based on individual on-farm guidelines, as recommended by FAO and IDF Guide to milking hygiene practices (FAO, 2011). After the accomplishment of the extension program, dairy farmers began to be paid according to the newly established milk payment policy (Table 2), which was applied to all dairy farmers delivering milk to the cooperative.

The payment policy consisted of a fixed premium per penalty on the milk price paid to the dairy producer, according to their achievement of each bulk tank parameter targeted by the central cooperative (Table 2), accordingly to the implementation schedule adopted by each of the four cooperatives. Cooperative B first implemented premiums and penalties to milk price in Nov. 2006. The cooperative $\mathrm{C}$ introduced incentives for FAT and PROT at the same time; later, in Apr. 2007, it included the other two variables. Cooperative $\mathrm{D}$ began to offer incentives by Apr. 2007, while cooperative A started by Dec. 2007. The adopted different schedules were due to internal factors of each cooperative, e. g., number of dairy producers and number of dairy producers assisted by dairy extension personnel. Furthermore, the central coopera-

Table 1 - Sample composition.

\begin{tabular}{|c|c|c|c|}
\hline & & Before implementation of QPP & After implementation of QPP \\
\hline \multirow{4}{*}{ Cooperative A } & Indicators & \multicolumn{2}{|c|}{ QPP for BTSCC, BTTBC, FAT and PROT } \\
\hline & Period & Feb. 2006 to Nov. 2007 & Dec. 2007 to Apr. 2008 \\
\hline & Months & 22 & 5 \\
\hline & $\mathrm{n}$ & 3,140 & 917 \\
\hline \multirow{4}{*}{ Cooperative B } & Indicators & \multicolumn{2}{|c|}{ QPP for BTSCC, BTTBC, FAT and PROT } \\
\hline & Period & Ago. 2005 to Oct. 2006 & Nov. 2006 to Apr. 2008 \\
\hline & Months & 15 & 18 \\
\hline & $\mathrm{n}$ & 697 & 893 \\
\hline \multirow{8}{*}{ Cooperative $\mathrm{C}$} & Indicators & \multicolumn{2}{|c|}{ QPP for FAT and PROT } \\
\hline & Period & Ago. 2005 to Oct. 2006 & Nov. 2006 to Apr. 2008 \\
\hline & Months & 15 & 18 \\
\hline & $\mathrm{n}$ & 2,246 & 4,215 \\
\hline & Indicators & \multicolumn{2}{|c|}{ QPP for BTSCC and BTTBC } \\
\hline & Period & Ago. 2005 to Mar. 2007 & Apr. 2007 to Apr. 2008 \\
\hline & Months & 20 & 13 \\
\hline & $\mathrm{n}$ & 3,616 & 2,845 \\
\hline \multirow{4}{*}{ Cooperative D } & Indicators & \multicolumn{2}{|c|}{ QPP for BTSCC, BTTBC, FAT and PROT } \\
\hline & Period & Nov. 2005 to Mar. 2007 & Apr. 2007 to Apr. 2008 \\
\hline & Months & 17 & 13 \\
\hline & $\mathrm{n}$ & 4,064 & 3,472 \\
\hline
\end{tabular}

Number of observations ( $n=19,644)$. QPP: Quality Premium Program; BTSCC: bulk tank somatic cells; BTTBC: bulk tank total bacterial count; FAT: fat percentage; PROT: protein percentage.

Table 2 - Premium and penalty program adopted by the central cooperative according to bulk tank somatic cell (BTSCC) and total bacterial counts (BTTBC) and stringency through the observed years of the payment policy.

\begin{tabular}{|c|c|c|c|c|c|}
\hline \multirow{2}{*}{ Year after implementation } & \multirow{2}{*}{ Parameter } & \multicolumn{4}{|c|}{ Premium/Penalty (US\$) } \\
\hline & & +0.0083 & +0.0028 & 0.0000 & -0.0111 \\
\hline \multirow{2}{*}{$1^{\text {st }}$} & BTSCC $\left(\times 10^{3}\right.$ cells $\left.\mathrm{mL}^{-1}\right)$ & $\leq 400$ & 401 up to 700 & 701 up to 1,000 & $>1,000$ \\
\hline & BTTBC $\left(\times 10^{3} \mathrm{cfu} \mathrm{mL}^{-1}\right)$ & $\leq 100$ & 101 up to 400 & 401 up to 1,000 & $>1,000$ \\
\hline \multirow{3}{*}{$2^{\text {nd }}$} & & +0.0139 & +0.0056 & 0.0000 & -0.0083 \\
\hline & BTSCC $\left(\times 10^{3}\right.$ cells $\left.\mathrm{mL}^{-1}\right)$ & $\leq 300$ & 301 up to 500 & 501 up to 750 & $>750$ \\
\hline & BTTBC $\left(\times 10^{3} \mathrm{cfu} \mathrm{mL}^{-1}\right)$ & $\leq 75$ & 75,001 up to 300,000 & 301 up to 750 & $>750$ \\
\hline
\end{tabular}

${ }^{1}$ Currency: US\$ $1.00=\mathrm{R} \$ 1.80$. 
tive had adopted a variable BTSCC and BTTBC premi$\mathrm{um} /$ penalty policy, with the level of stringency based on the targeted parameters over two years of evaluation of the payment program. For milk with fat concentration higher than $3.2 \%$, a premium of US $\$ 1.44$ per kg of extra fat was paid; for protein concentration above $3.1 \%$, a premium of US $\$ 2.77$ per $\mathrm{kg}$ of extra protein was paid (Note: US\$ $1.00=\mathrm{R} \$ 1.80$ ).

All data were analyzed using SAS version 9.2 (SAS Institute, Cary, NC, USA). Descriptive analysis of milk variables by month was performed using PROC MEANS. To identify possible effects over each of these four variables, ANOVA was conducted using PROC GLM. Tested effects were: seasonality, daily average volume of milk, premium payment/deduction, producer and cooperative. Seasonality was modeled as suggested by Nightingale et al. (2008), using a sine-cosine function to represent annual variation of the effect over variables. The seasonal function was:

$\beta_{1} \operatorname{Sin}[2 \pi \times($ month $/ 12)]+\pi_{2} \operatorname{Cos}[2 \pi \times($ month / 12) $]$

Once relevant effects were identified, multiple linear regression models were estimated, attempting to measure such influence over the four considered milk quality variables, using PROC MIXED:

$\mathrm{BTSCC}=\alpha+\beta_{1} \operatorname{Sin}()+.\beta_{2} \operatorname{Cos}()+.\beta_{3} \mathrm{QPP}+\beta_{4} \operatorname{CoopB}+\beta_{5} \operatorname{CoopC}+\beta_{6} \operatorname{CoopD}+\varepsilon$

BTTBC, FAT and PROT were estimated using similar models.

The econometric linear multiple regression model estimated $\alpha$ and $\beta_{1}$ to $\beta_{6}$ parameters. Seasonality effect was adjusted by $\beta_{1}$ and $\beta_{2}$ parameters, as previously described. The variable Quality Premium Program period (QPP) is of particular interest to this research, as it aimed to measure the effect of the premium program implementation on the considered milk quality parameters. A dummy variable represented QPP, being 0 (zero) for the milk delivered before the institution of the program, and 1 (one) for milk delivered to the cooperatives after the program implementation. A set of other dummy variables was included to estimate each cooperative's influence on milk quality parameters. Once the four co- operatives were involved (A, B, C and D), only three other dummy variables had to be include in the model to avoid perfect multicollinearity (a statistical phenomenon in which two or more predictor variables in a multiple regression model are correlated) (Greene, 1993).

The units for the dependent variables were: cells $\mathrm{mL}^{-1}$ for BTSCC, cfu $\mathrm{mL}^{-1}$ for BTTBC, and percentage (\%) for FAT and PROT. The choice of variables was based on two grounds: i) proposed by previous studies (Nightingale et al., 2008), Schukken et al. (1992a) and Schukken et al. (1992b); and ii) variables covered by the quality program of the analyzed cooperatives: the data were obtained from the cooperatives themselves, so that the variables used were those included in their programs.

\section{Results and Discussion}

The total number of observations used in this study was 19,644, collected from 1,075 dairy farmers. Average, number of observations (sample size) and standard deviation for BTSCC, BTTBC, FAT and PROT of milk of the four cooperatives are shown in Table 3. During the study, $10.4 \%$ of the delivered milk exceeded the Brazilian BTSCC legal limit of 750,000 cells $\mathrm{mL}^{-1}$. Similarly, $35.8 \%$ was above the Brazilian BTTBC legal limit of $750,000 \mathrm{cfu} \mathrm{mL}^{-1}$.

BTSCC and BTTBC were influenced by all variables included in the model (Table 4). Figure 1 shows average BTSCC and average BTTBC according to season variation in the course of the study, whilst Figure 2 illustrates the relation between average BTSCC and the size of the farms, represented by the daily average volume of delivered milk.

FAT of delivered milk was influenced by premium incentives and dairy producer. Seasonality and cooperative significantly affected fat percentage as well. Daily

Table 3 - Descriptive analysis of the bulk tank somatic cell (BTSCC), total bacterial counts (BTTBC), fat (FAT), and protein (PROT) of milk shipped by the central cooperative during the period of data collection.

\begin{tabular}{lrc}
\hline Variable & \multicolumn{1}{c}{ Mean } & Standard deviation \\
\hline BTSCC $\left(\times 10^{3} \mathrm{cells} \mathrm{mL}^{-1}\right)$ & 393.87 & 316.77 \\
BTTBC $\left(\times 10^{3} \mathrm{cfu} \mathrm{mL}^{-1}\right)$ & $1,543.88$ & $2,926.72$ \\
FAT $(\%)$ & 3.50 & 0.52 \\
PROT $(\%)$ & 3.22 & 0.17 \\
\hline
\end{tabular}

Number of observations $(n=19,644)$.

Table 4 - ANOVA of seasonality, daily volume, premium/penalty, producer, cooperative on bulk tank somatic cell (BTSCC), total bacterial count (BTTBC), fat (FAT) and protein (PROT).

\begin{tabular}{|c|c|c|c|c|c|c|c|c|}
\hline $\begin{array}{l}\text { Cause of } \\
\text { variation }\end{array}$ & $\begin{array}{c}\text { BTSCC } \\
\text { Sum of squares }\end{array}$ & $P$ & $\begin{array}{c}\text { BTTBC } \\
\text { Sum of squares }\end{array}$ & $P$ & $\begin{array}{c}\text { FAT } \\
\text { Sum of squares }\end{array}$ & $P$ & $\begin{array}{c}\text { PROT } \\
\text { Sum of squares }\end{array}$ & $P$ \\
\hline Sine & 482,334 & $<.0001$ & $127,269,792$ & $<.0001$ & 5.65 & $<.0001$ & 0.351 & $<.0001$ \\
\hline Cosine & 182,906 & 0.0119 & $14,690,910$ & 0.0054 & 9.66 & $<.0001$ & 1.67 & $<.0001$ \\
\hline Daily volume & 252,471 & 0.0031 & $16,508,878$ & 0.0032 & 0.00005 & 0.9510 & 0.028 & 0.0019 \\
\hline Premium/Penalty & $21,848,213$ & $<.0001$ & $252,741,325$ & $<.0001$ & 443.46 & $<.0001$ & 0.235 & $<.0001$ \\
\hline Producer & $301,453,198$ & $<.0001$ & $21,929,851$ & $<.0001$ & 111.51 & $<.0001$ & 0.0143 & $<.0001$ \\
\hline Cooperative & $6,268,321$ & $<.0001$ & $90,934,817$ & $<.0001$ & 0.453 & $<.0001$ & 0.0046 & 0.1949 \\
\hline
\end{tabular}

Number of observations $(n=19,644)$. 


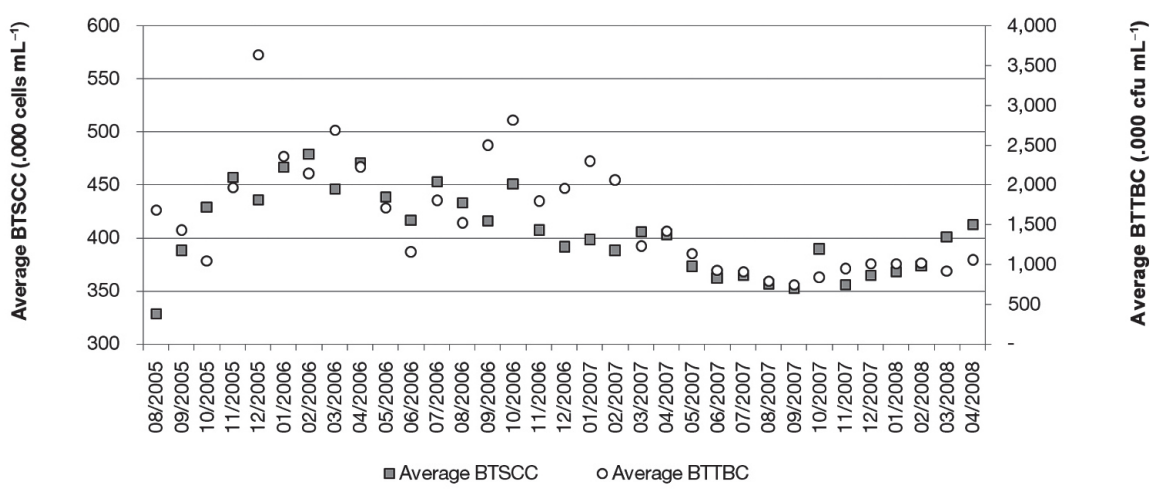

Figure 1 - Monthly average of bulk tank somatic cell count (BTSCC) and total bacterial count (BTTBC) during the study period.

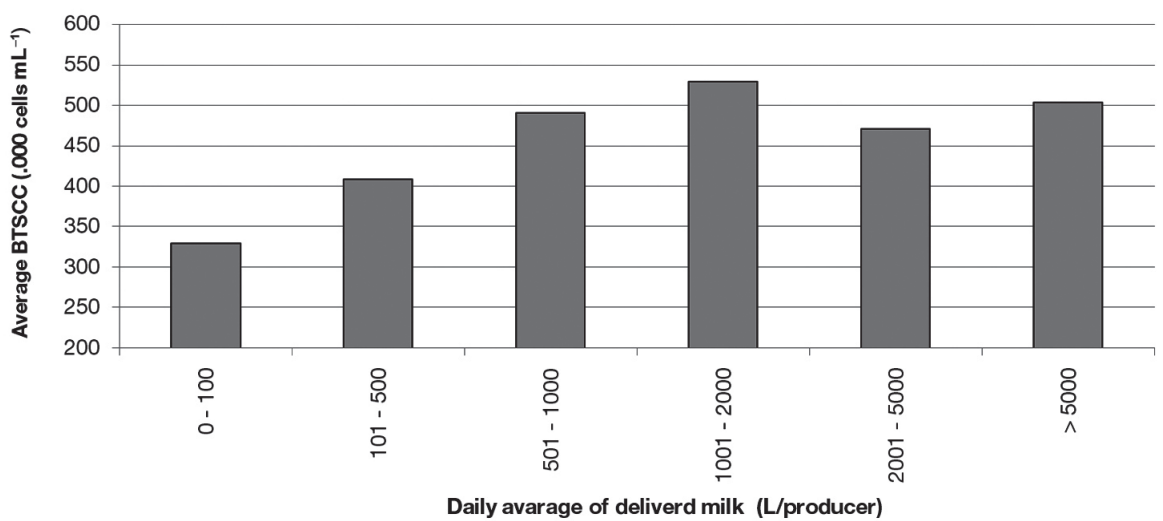

Figure 2 - Average of bulk tank somatic cell count (BTSCC) according to the daily average volume of delivered milk.

volume delivered did not exert any influence on this parameter. PROT was influenced by all variables included in the model, except the cooperative one.

The results for the multiple linear regression models are presented in Table 5. The set of dummy values related to cooperatives was not included on the PROT model as the cooperative did not seem to affect PROT (Table 4). When data concerning the four cooperatives were considered, three dummy values had to be used $(C o o p B, C o o p C$ and $C o o p D)$. Thus, the set for cooperative "A" was: $\operatorname{Coop} B=0 ; \operatorname{Coop} C=0 ; \operatorname{CoopD}=0$; the one related to cooperative " $\mathrm{B}$ " was: $\operatorname{Coop} B=1$; $\operatorname{Coop} C$ $=0 ; \operatorname{CoopD}=0$; and so on. The daily volume was not included in the regression model, due to the lack of this information for some observations of the sample.

Implementation of the milk quality premium program had a significant effect on BTSCC, reducing it by more than 65,000 cells $\mathrm{mL}^{-1}$ (Table 5). The reduction of 65,000 cells $\mathrm{mL}^{-1}$ was obtained as a result of parameter estimates (Table 5) by the regression model for binary variable that represented the beginning of the period of payment for quality. The variable had value 0 (zero) for the months before the beginning of the program, and it had value 1 (one) after it had started. The fact that the parameter has been estimated at 65,000 suggests that irrespective of other variables - the SCC was reduced by this magnitude after the implementation of the program. BTSCC throughout the period was 393,870 cells $\mathrm{mL}^{-1}$ (Table 3), thus suggesting that the reduction of 65,000 was representative.

The regression model could ratify the cooperative effect, with the three dummy values being similar (between 84 and $88 \times 10^{3}$ cells $\mathrm{mL}^{-1}$ ), and with significant effect on BTSCC. The estimated regression parameter for BTSCC of cooperative "A" was higher compared to the others. Considering cooperative effects, for " $\mathrm{B}$ ", " $\mathrm{C}$ " and " $\mathrm{D}$ " the program itself was able to reduce the original counting of somatic cell by around $16 \%$ [65.07//489.34988.25) for B; 65.07/(489.349-84.29) for C; 65.07/(489.349$87.59)$ for $\mathrm{D}]$, whilst values observed in cooperative " $\mathrm{A}$ " (65.07/489.349) had achieved reductions up to $13.3 \%$.

BTTBC was also reduced by the milk quality premium program (Table 5). Nevertheless, in contrast to the SCC, there was a wide original variation among cooperatives. For cooperative "B", the payment program contributed to a reduction of more than $90 \%$ in the overall BTTBC [1,044.72/(1,486.09-355.70)]. For cooperatives "C", "D" and "A" the reductions were $39.4 \%[1,044.72 /$ 
$(1,486.09+1,167.33)], 58.7 \%[1,044.72 /(1,486.09+292.89)]$ and $70.3 \%(1,044.72 / 1,486.09)$, respectively.

The adoption of the milk quality-based payment varied among cooperatives, and had an interestingly, small negative association between fat percentage of milk (Table 6). In contrast, seasonality influenced BTSCC and BTTBC. The cooperative effect was not uniform as well. Dairy producers from cooperatives $\mathrm{C}$ and $\mathrm{D}$ had delivered milk with higher fat percentages than those from cooperatives B and A. The reason for this could not be established, and further research is suggested to clarify this point.

Similarly to fat percentage, milk protein was not affected by the adoption of a quality premium program by the cooperatives considered in this study, when the multiple regression model was used to evaluate it. Seasonality showed effect on protein levels (Table 4). Because the model analyzed real data from the market instead of data from experimental results specifically designed for this proposal, it was not possible to control the adoption of correct and accurate recommendations for the producers.

The premium per penalty payments had significant association with quality parameters established by the central cooperative. Results of this study suggested that the producer was the only factor that influenced all dependent variables. Farmer's average daily volume delivered did not contribute significantly to milk quality attributes, in contrast to information previously shown by other studies (Nightingale et al., 2008). The BTSCC pat- tern observed (specifically the peak in rainy seasons and the reduction in dry ones - Figure 1) was expected and followed the same trends as described in previous reports on similar climate conditions (Botaro et al., 2008).

Establishment of a milk quality premium program played a key role in motivating dairy producers to focus their efforts on farm management practices that control mastitis, as referred by BTSCC. Previous studies have shown the impact of penalty (Sargeant et al., 1998) and premium approaches (Nightingale et al., 2008) on lowering population mean SCC. Although a penalty program had shown to be effective in decreasing overall mean BMSCC (Sargeant et al., 1998), further reductions would be achieved if a combination of a penalty program for high BTSCC. Financial incentives targeting low BTSCC were adopted (Nightingale et al., 2008), as it was implemented by the central cooperative here studied. However, the multivariate model used in the present study could not distinguish which parameter was the most effective on improving mastitis control at the farm level. Another area of concern yet to be investigated is the apparent adverse effect that a BTSCC reduction program has on the increase of subclinical cases of mastitis treated during lactation. This is especially important and must be studied in this kind of scenario once the overtreatment of subclinical mastitis aiming at reducing SCC (Østerås and Sølverød, 2009) may lead to an increased risk of inhibitor violations.

Table 5 - Effects of bulk tank somatic cell count (BTSCC) and total bacterial count (BTTBC) by each of the considered factors estimated by the multiple linear regression model.

\begin{tabular}{|c|c|c|c|c|c|c|}
\hline \multirow[b]{2}{*}{ Effect } & \multicolumn{3}{|c|}{ BTSCC } & \multicolumn{3}{|c|}{ BTTBC } \\
\hline & $\begin{array}{l}\text { Estimated } \\
\text { parameter }\end{array}$ & Standard deviation & $P$ & $\begin{array}{l}\text { Estimated } \\
\text { parameter }\end{array}$ & Standard deviation & $P$ \\
\hline & \multicolumn{3}{|c|}{-------------------- $\times 10^{3}$ cells mL $^{-1}$-------------------- } & \multicolumn{3}{|c|}{ 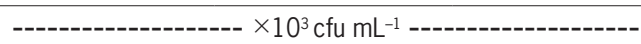 } \\
\hline Intercept & 489,349 & 5.02 & $<.0001$ & $1,486.09$ & 45.53 & $<.0001$ \\
\hline Sine & 5.94 & 3.12 & 0.056 & 102.31 & 28.30 & 0.0003 \\
\hline Cosine & -4.80 & 3.22 & 0.1364 & 236.64 & 29.25 & $<.0001$ \\
\hline Quality Program (QPP) & -65.07 & 4.66 & $<.0001$ & $-1,044.72$ & 42.21 & $<.0001$ \\
\hline Cooperative B & -88.25 & 9.38 & $<.0001$ & -355.70 & 85.027 & $<.0001$ \\
\hline Cooperative C & -84.29 & 6.34 & $<.0001$ & $1,167.33$ & 57.47 & $<.0001$ \\
\hline Cooperative D & -87.59 & 6.19 & $<.0001$ & 292.89 & 56.07 & $<.0001$ \\
\hline
\end{tabular}

Number of observations $(\mathrm{n}=19,644)$.

Table 6 - Effects on fat (FAT) and protein percentages (PROT) by each of the considered factors estimated by the multiple linear regression model.

\begin{tabular}{|c|c|c|c|c|c|c|}
\hline \multirow[b]{2}{*}{ Effect } & \multicolumn{3}{|l|}{ FAT } & \multicolumn{3}{|l|}{ PROT } \\
\hline & $\begin{array}{l}\text { Estimated } \\
\text { Parameter }\end{array}$ & Standard deviation & $P$ & $\begin{array}{l}\text { Estimated } \\
\text { Parameter }\end{array}$ & Standard deviation & $\mathrm{P}$ \\
\hline Intercept & 3.487 & 0.008 & $<.0001$ & 3.230 & 0.0015 & $<.0001$ \\
\hline Sine & -0.015 & 0.005 & 0.002 & 0.014 & 0.0016 & $<.0001$ \\
\hline Cosine & -0.188 & 0.005 & $<.0001$ & -0.066 & 0.0017 & $<.0001$ \\
\hline Quality Program (QPP) & -0.0186 & 0.007 & 0.013 & -0.004 & 0.0024 & 0.0824 \\
\hline Cooperative B & -0.024 & 0.0151 & 0.107 & - & - & - \\
\hline Cooperative $\mathrm{C}$ & 0.065 & 0.010 & $<.0001$ & - & - & - \\
\hline Cooperative D & 0.0414 & 0.0099 & $<.0001$ & - & - & - \\
\hline
\end{tabular}

Number of observations $(n=19,644)$. 
Although BTSCC is the key regulatory component in international trading for milk (Van Schaik et al., 2002), BTTBC is another cutoff element in dairy markets. In terms of bacterial counts, approximately $36 \%$ of all milk delivered in the considered sample was not in compliance with the national regulatory criteria for milk quality (< $750,000 \mathrm{cfu} \mathrm{mL}^{-1}$ ). The adoption of a combined program targeting those variables resulted in a significant improvement of milk hygiene quality in the sampled milk of the cooperatives. Thus, a combined premium + penalty program would not only help the country's dairy industry in achieving better quality dairy products but also in suiting requirements enforced by internal dairy regulations. Nevertheless, these efforts have contributed to neither increased FAT nor PROT percentages. On the other hand, seasonality had a higher impact on milk composition compared with udder health and milk hygiene status (Tables 5 and 6).

There was an association between the incentive program in the cooperatives and the three out of the four considered dependent milk quality variables. Protein percentage was the only unresponsive variable influenced by the cooperative. All the results regarding cooperatives have special importance for the Brazilian dairy industry, once the sector has been experiencing huge structural changes, such as steady increase in milk production, concentration of the processing sector (Barros et al., 2001), and stricter BTSCC and BTTBC regulations (Brasil, 2002).

The results suggest that the "producer-cooperative" relationship had affected milk quality, once the extension program coordinated by the cooperative certainly played a central role in this process. In other words, financial rewards induce changes in milk quality, especially decreases in bulk tank somatic cell and total bacterial counts. However, some changes regarding milk composition were not quite evident by rewarding dairy producer and might be dependent on other effective long-term factors such as herd nutrition, animal breeding and genetics. Such strategies might be related, for instance, to dairy farmer awareness, institutional communication, educational activities and motivation, and shall be addressed in further studies.

\section{Acknowledgements}

To Dr. Adrian Molenaar, from AgResearch Ltd., Ruakura Research Centre (Hamilton, New Zealand), for his assistance with the textual analysis and careful English revision of this manuscript.

\section{References}

Auldist, M.J.; Hubble, I.B. 1998. Effects of mastitis on raw milk and dairy products. Australian Journal of Dairy Technology 53: $28-36$.

Barbano, D.M.; Y. Ma; Santos, M.V. 2006. Influence of raw milk quality on fluid milk shelf life. Journal of Dairy Science 89 (sup.): E15-19.
Barros, G.S.C.; Galan, V.B.; Guimarães, V.A.; Bacchi, M.R.P. 2001. Sistema agroindustrial do leite no Brasil = Dairy Agri-industrial system in Brazil. Embrapa Informação Tecnológica, Brasília, DF, Brazil (in Portuguese).

Botaro, B.G.; Lima, Y.V.R.; Aquino, A.A.; Fernandes, R.H.R.; Garcia, J.F.; Santos, M.V. 2008. Effect of beta-lactoglobulin polymorphism and seasonality on bovine milk composition. Journal of Dairy Research 75: 176-181.

Brasil. 2002. Instrução normativa $n^{\circ} 51$, de 20 de setembro de 2002. Regulamento Técnico de Produção, Identidade e Qualidade do Leite Cru Refrigerado = Technical Regulation of Production, Identity and Quality of Refrigerated Raw Milk. Diário Oficial da União, Brasília, DF, Brazil (in Portuguese).

Dekkers, J.C.M.; VanErp, T.; Schukken, Y.H. 1996. Economic benefits of reducing somatic cell count under the milk quality program of Ontario. Journal of Dairy Science 79: 396-401.

Draaiyer, J.; Dugdill, B.; Bennett, A.; Mounsey, J. 2009. Milk testing and payment systems resource book: a practical guide to assist milk producer groups. Food and Agriculture Organization, Rome, Italy.

Food and Agriculture Organization [FAO]. 2011. Milking hygiene. In: Guide to good dairy farming practice. FAO, Rome, Italy. p. 17-21. (Animal Production and Health Guidelines, 8). Available at: http://www.fil- idf.org/Public/Download.php?media $=38836$ [Accessed Dec. 8, 2011]

Greene, W. 1993. Econometric Analysis. Prentice-Hall, Englewood Cliffs, NJ, USA. Nettle, R.A.; Weatherley, J.; Paine, M. 2003. Groups orone to one? Rethinking extension delivery: learningsfrom the dairy industry. Australasian Pacific Extension Network Forum, p. 26-28. Available at: http://www.regional.org.au/au/apen/2003/ refereed/075nettlera.htm [Accessed Oct. 20, 2010]

Nightingale, C.; Dhuyvetter, K.; Mitchell, R.; Schukken, Y.H. 2008. Influence of variable milk quality premiums on observed milk quality. Journal of Dairy Science 91: 1236-1244.

Østerås, O; Sølverød, L. 2009. Norwegian mastitis control program. Irish Veterinary Journal 62: 26-33.

Sargeant, J.M.; Schukken, Y.H.; Leslie, K.E. 1998. Ontario bulk milk somatic cell count reduction program: progress and outlook. Journal of Dairy Science 81: 1545-1554.

Schukken, Y.H.; Leslie, K.E.; Weersink, A.J.; Martin, S.W. 1992a. Ontario bulk milk somatic-cell count reduction program. 1. Impact on somatic-cell counts and milk quality. Journal of Dairy Science 75: 3352-3358.

Schukken, Y.H.; Leslie, K.E.; Weersink, A.J.; Martin, S.W. 1992b. Ontario bulk milk somatic cell count reduction program. 2. Dynamics of bulk milk somatic-cell counts. Journal of Dairy Science 75: 3359-3366.

Valeeva, N.I.; Lam, T.J.G.M.; Hogeveen, H. 2007. Motivation of dairy farmers to improve mastitis management. Journal of Dairy Science 90: 4466-4477.

Van Schaik, G.; Lotem, M.; Schukken, Y.H. 2002. Milk quality in New York State: trends in somatic cell counts, bacterial counts, and antibiotic residue violations in New York State in 19992000. Journal of Dairy Science 85: 782-789. 